\title{
Programmed Cell Death in Procyclic Form Trypanosoma brucei rhodesiense - Identification of Differentially Expressed Genes during Con A Induced Death
}

\author{
Susan C Welburn/ ${ }^{+}$, Simon Lillico*, Noel B Murphy**
}

\begin{abstract}
Centre for Tropical Veterinary Medicine, The University of Edinburgh, Easter Bush, Roslin, Midlothian, Scotland, EH25 9RG * Division of Molecular Genetics, IBLS, University of Glasgow, 56 Dumbarton Road, Glasgow, G116NU, U.K **International Livestock Research Institute, Nairobi, PO Box 30709
\end{abstract}

Trypanosoma brucei rhodesiense can be induced to undergo apoptosis after stimulation with Con A. As cell death in these parasites is associated with de novo gene expression we have applied a differential display technique, Randomly Amplified Differential Expressed Sequence-Polymerase Chain Reaction (RADES-PCR) to the study of gene expression during Con A induced cell death in these organisms. Twenty-two differentially displayed products have been cloned and sequenced. These represent the first endogenous genes to be identified as implicated in cellular death in trypanosomatids (the most primitive eukaryote in which apoptosis has been described). Evidence for an ancestral death machinery, 'protoapoptosis' in single celled organisms is discussed.

Key words: Trypanosoma brucei rhodesiense - programmed cell death - apoptosis - differential gene expression proto-apoptosis

Programmed cell death (PCD) and apoptosis comprise a well established genetically controlled cellular "suicide" mechanism in eukaryotes which leads to elimination of unnecessary or damaged cells. Originally described in mammals and later in Caenorhabditis elegans, a controlled death program is considered essential for the proper development and functioning of a cell system, organ, or for survival of the organism as a whole. Recently $\mathrm{PCD} /$ apoptosis has been described in several lower organisms including the slime mould Dictyostelium discoideum (Cornellion et al. 1994) and several single celled members of the parasitic protozoa: Trypanosoma cruzi (Ameisen et al. 1995); T. brucei rhodesiense (Welburn et al. 1996); Leishmania L. amazonenis (Moiera et al. 1996) and Plasmodium falciparum (Picot et al. 1997).

The demonstration of apoptosis in three members of the trypanosomatids has implications for our understanding of the origins of PCD in eukaryotic cell survival as these organisms represent the most primitive eukaryotes in which it has been

This work is supported by the Wellcome Trust (Career Development Award to SCW), IBLS, University of Glasgow studentship programme (SL) and the Animal Health Programme of ILRI (NBM).

${ }^{+}$Corresponding author. Fax:+44-131-445.5099. E-mail: sue.welburn@tsetse.demon.co.uk

Received 12 November 1998

Accepted 19 January 1999 described. The identification of genes that regulate cell suicide in these unicellular organisms is essential to address issues such as the social control of cell survival and whether unicellular eukaryotes share the same or similar regulators of cell suicide programmes with multicellular organisms (for reviews see: Ameisen 1996, Welburn et al. 1997).

It is well established in metazoan organisms that cell death is often an active process triggered by signals that induce crude biochemical changes in target cells resulting in many cases in changes in patterns of gene expression (Baudet et al. 1998). Several genes have been found to play a critical role in the apoptosis pathway in metazoan cells with their activation triggering or leading to the progression of cell death. In mammalian cells these include the proto-oncogene C-myc (Evan et al. 1992), nuclear regulatory factors encoded by the p53 gene (Lowe et al. 1993) and several non-nuclear components such as members of the bcl/bax gene family (Larsen 1994) or the Fas/apo-1 receptor (Trauth et al. 1989); in C. elegans these include the cell death genes ced 3, ced 4 and ced 9 (Hengartner 1997). It is clear that these genes are not acting in isolation and that the pathways leading to cell death are complex; similarly in lower organisms the process is likely to involve many genes.

We have shown that trypanosomes can be induced to undergo apoptosis after stimulation with Con A and that the process of death is associated with de novo gene expression (Welburn et al.1996, Murphy \& Welburn 1997, Welburn \& Murphy 
1998). To provide an overview of the genetic changes occurring during the execution of the cell death program in $T$. $b$. rhodesiense, we have used a differential display method [Randomly Amplified Developmentally Expressed Sequences-PCR (RADES-PCR)] for the identification of genes which are differentially expressed in cells which have been induced to die. These differentially expressed genes and their encoded products may be implicated directly or indirectly in the cell death mechanism.

\section{MATERIALS AND METHODS}

Trypanosomes - Bloodstream form $T . b$. rhodesiense (stock OBWANG isolated from a patient during a sleeping sickness epidemic in S. E. Uganda, 1990) were transformed to procyclic (insect form) parasites by transmission through tsetse flies. Trypanosomes were dissected from tsetse guts and cultured at $27^{\circ} \mathrm{C}$ in Cunningham's medium (CM) supplemented with $20 \%$ foetal bovine serum (Cunningham 1977).

Induction of apoptosis - Log-phase trypanosomes $\left(10^{6} / \mathrm{ml}\right)$ were incubated with Con A type IV (Sigma, UK) at $1-10 \mathrm{mg} / \mathrm{ml}$ in procyclic culture media (Cunningham's medium supplemented with $17 \%$ foetal bovine serum) and harvested 0, 2, 4, 7, 24,48 and $72 \mathrm{hr}$ after treatment as previously described (Welburn et al. 1996, Welburn \& Murphy 1998).

Preparation of RADES template - Total RNA was prepared from parasites at each time point of Con A treatment $(0,2,4,7,24$ and $48 \mathrm{hr})$ and analysed by gel electrophoresis. RNA was enriched for polyadenylated transcripts and conversion to cDNA was effected using Moloney murine leukemia virus (M-MLV), reverse transcriptase and an oligo (dT) primer (TAG GCG CGC CTT TTT TTT TTT TTT TTT TTT). After removal of oligo $\mathrm{d}(\mathrm{T})$ primer and dNTPs via a Centricon 30 column (Amicon), ds cDNA was generated using a specific primer for the conserved $25 \mathrm{nt}$ at the 3 ' end of the miniexon spliced leader of all trypanosome mRNAs (TAG GCG CGC CTA GAA CAG TTT CTG TAC TAT ATT G) containing nt 16 to 39 of the miniexon sequence and the oligo (dT) primer. PCRs contained $100 \mathrm{ng}$ cDNA /10 ml 10X Taq buffer [10mM TrisHCL (pH8.3)] $2 \mathrm{mM} \mathrm{MgCl} / \mathrm{ml} /$ $4 \mathrm{ml} 5 \mathrm{mM}$ dNTPs/ 12.5 units Taq DNA polymerase/ $1 \mathrm{ml}(100 \mathrm{ng} / \mathrm{ml})$ each of the oligo(dT) primer and miniexon primer in $100 \mathrm{ml}$ total volume. Cycling conditions were $94^{\circ} \mathrm{C}$ for $1 \mathrm{~min}, 55^{\circ} \mathrm{C}$ for $1 \mathrm{~min}$ and $72^{\circ} \mathrm{C}$ for $2 \mathrm{~min}$ for 40 cycles followed by a 5 min extension at $72^{\circ} \mathrm{C}$. Buffer, primers and dNTPs were removed by ultrafiltration in a Centricon 30 column (Amicon, Inc.). cDNAs were collected and diluted to $20 \mathrm{ng} / \mathrm{ml}$ in TE.
RADES-PCR - Double-stranded cDNA served as the template for arbitrary primers in the subsequent RADES-PCR fingerprinting reactions. PCR reactions were carried out at two template concentrations to check the reproducibility the fingerprints. PCR reactions were carried out using single arbitrary 10 mer primers (Murphy \& Pelle 1994, Murphy \& Welburn 1997, Welburn \& Murphy 1998). PCRs contained $20 \mathrm{ng}$ or $2 \mathrm{ng}$ of target cDNAs and the volume brought to $10 \mathrm{ml}$ with water $/ 10 \mathrm{mM}$ Tris-HCL $(\mathrm{pH} 8.3) / 50 \mathrm{mM} \mathrm{KCl} / 3 \mathrm{mM}$ $\mathrm{MgCl} / 0.05 \%$ (v/v) NP40 / 0.05\% v/v Tween 20/ $200 \mathrm{mM}$ of dNTPs / $0.6 \mathrm{mM}$ primer/ 0.5 units of Taq (Thermus aquaticus) DNA polymerase (Promega) in a volume of $20 \mathrm{ml}$, and were performed on a programmable thermal cycler. $\mathrm{Cy}$ cling conditions were $94^{\circ} \mathrm{C}$ for $45 \mathrm{~s}, 40^{\circ} \mathrm{C}$ for $1 \mathrm{~min}$ and $72^{\circ} \mathrm{C}$ for $1 \mathrm{~min}$ for 40 cycles followed by a $72^{\circ} \mathrm{C} 5 \mathrm{~min}$ extension. Amplification products were analysed by electrophoresis in $3 \%(\mathrm{w} / \mathrm{v})$ MetaPhor ${ }^{\hat{a}}$ agarose gel and detected by UV illumination following staining with EtdBr.

Re-amplification and cloning of RADES products - RADES products were gel extracted and reamplified using the PCR conditions described above. An A-tailing procedure was performed to increase the efficiency of cloning of differentially expressed cDNAs, (two units Taq DNA polymerase and dATP added to a final concentration of $0.6 \mathrm{mM}$, incubated at $70^{\circ} \mathrm{C}$ for $15 \mathrm{~min}$ ). Amplified cDNAs were identified by electrophoresis as above and subsequently cleaned by gel purification (Geneclean II kit, Bio 101, Inc). A-tailed cDNAs were ligated into GEMM $^{\hat{a}}$-T vector (Promega) and successfully transformed into Escherichia coli strain JM109 high efficiency competent cells (Promega) by use of the Promega heat-shock method. Blue/white screening was used to identify recombinant plasmids, which were subsequently purified using the plasmid preparation method of Qiagen. Inserts carried by the clones corresponding to differentially expressed RNAs were analysed by automated sequencing. Sequences were compared to the GENBANK/EMBL sequence databases using BLAST (basic local alignment search tool) programme (Altschul et al. 1990) and Gapped BLAST programmes (Altschul et al. 1997).

Electron microscopy - Trypanosomes were cultured as described above and treated with Con A. Cells were examined $3 \mathrm{hr}$ after treatment with Con A to examine morphological evidence of apoptosis. Cells were washed in PBS then fixed in 3\% cacodylate buffered gluteraldehyde ( $\mathrm{pH} 7.3$ containing $0.01 \%$ calcium chloride) after centrifugation $(10 \mathrm{~min} 500 \mathrm{x} \mathrm{g})$ and processed for electron microscopy. 


\section{RESULTS}

Concanavalin A induced death in trypanosomes - Procyclic trypanosomes when treated with the lectin Con A die by a process essentially similar to the process of apoptosis in mammals (Welburn et al. 1996). Electron micrographs of procyclic trypanosomes treated with Con A showed the characteristic phenotype of apoptotic cells which includes surface membrane vesiculation and chromatin condensation (Wyllie et al. 1980). Three hours post-treatment with Con A trypanosomes exhibit condensation and marginalisation of chromatin to the periphery of the nuclear membrane (Figure). A proportion of treated cells appear multinucleate. These results confirm that treatment with Con A triggers a cell death mechanism in T. $b$. rhodesiense similar to the process of apoptosis described in metazoa which may be described as 'proto-apoptosis'.

It is not unusual for a lectin to induce apoptosis in metazoan cells, indeed apoptosis is classically initiated by binding of a cellular or cytoplasmic receptor which generate second messengers (Arends \& Wyllie 1991). Several lectins have been shown to trigger the activation of programmed cell death in tumour cells resulting in DNA fragmentation (Janssen et al. 1993, Kim et al. 1993). Con A has been shown to induce apoptosis in macroph- ages (Kong et al. 1996) and in synchronised T cell hybridomas in which activation-induced cell death resulted in all cells entering apoptosis shortly after reaching G2/M (Fotedar \& Fotedar 1995). Susceptibility of cells to apoptosis often depends on their state of differentiation and cell-cycle checkpoints may also serve to link the cell cycle to apoptosis. Although cell-cycle components may not be involved in all forms of apoptosis, in many instances cell proliferation and cell death share common pathways (King \& Cidlowski 1995).

Cross-linking of membrane receptors with Con A has also been shown to trigger programmed cell death in neurons which also exhibited an increase in c-Jun, an intermediate early gene product correlated with activation-induced programmed cell death in lymphocytes (Cribs et al. 1996, Azizeh et al. 1998). Similarly, Con A- induced CTLA-4 crosslinking on the surface of activated murine CD4(+) $\mathrm{T}$ lymphocytes leads to death of a substantial fraction of the cells whereas in resting CD4(+) T cells the same stimulation induces cell cycle arrest without apoptosis (Scheipers \& Reiser 1998).

The predominant cell surface glycoprotein of procyclic form trypanosomes, PARP (Richardson et al. 1988), is rich in mannose residues which would provide an ideal ligand for Con A. Cell death in vivo in the tsetse fly vector can be pre-

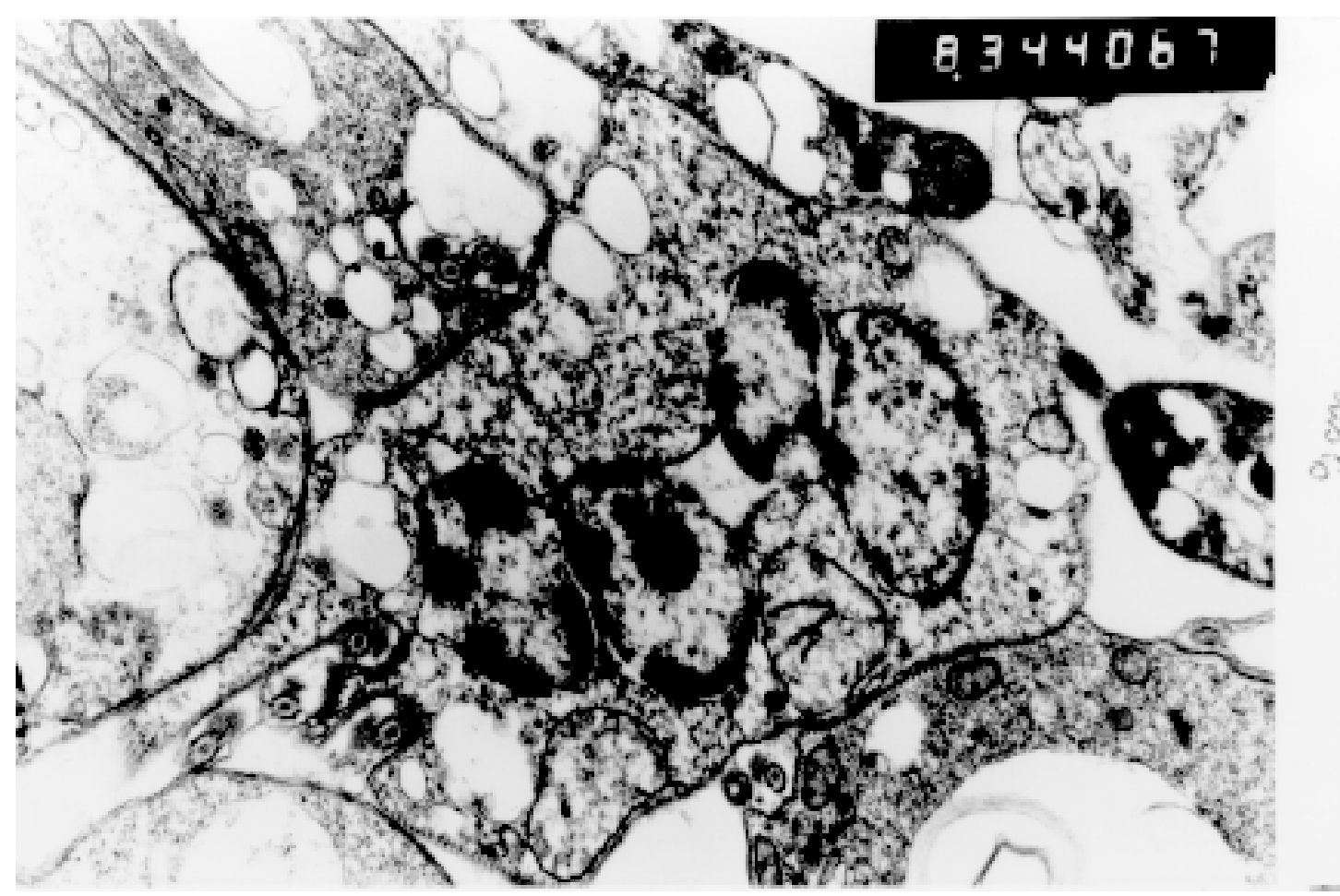

Electron micrographs showing morphological changes in Con A-treated procyclic Trypanosoma brucei rhodesiense. Agglutinated multi-nucleate procyclic trypanosomes $3 \mathrm{hr}$ after Con A treatment showing condensation and migration of chromatin to form crescents at the periphery of the nuclear membrane of the cell $(\mathrm{x} \mathrm{16,600)}$. 
vented by feeding purified PARP in the diet (Welburn \& Pearson, man. in prep.) Taken together these results suggest that death in procyclic parasites may be effected through Con A binding to PARP on the trypanosome surface.

Gene expression during ConA induced death of trypanosomes - To provide an overview of the genetic changes occurring during the death programme we have used an approach based on the identification of genes that are differentially expressed in parasites committed to die. As cell death in these parasites is associated with de novo gene expression (Welburn et al. 1996, Murphy \& Welburn 1997) these genes may be implicated directly or indirectly in the death mechanism. Although it is a reasonable assumption that a cell death programme is directly controlled by the induction of several genes which are expressed at a very low level, it should not exclude the possibility that cell death might ultimately result from changes in the expression of some housekeeping genes (Baudet et al. 1998).

Overview of differentially expressed genes Using RADES-PCR for differential display of cDNAs we have been able to identify genes which are differentially expressed during ConA induced death in T. $b$. rhodesiese. Twenty-two cDNAs have been cloned and sequenced. The majority of cDNAs which are differentially expressed after the parasites have been signalled to die are novel in trypanosomes but some have homologues in mammals, C. elegans or yeast. The differentially expressed cDNAs identified during Con A induced death in T. $b$. rhodesiense fall into several categories. Of the cloned cDNAs 13 clones carried inserts whose sequences are homologous to mammalian or invertebrate genes of which three have already been identified in typanosomatids and five clones represented homologues to ribosomal proteins. One clone carried an insert unique to trypanosomes. Eight clones carried inserts carried inserts with novel sequences. Five of the cDNA clones with homologues to mammalian or invertebrate genes represent ribosomal genes (two 40s and three 60s ribosomal proteins) and another is homologous to a peptide chain release factor. Genes relating to cell signalling and cellular communication include TRACK, a receptor for protein kinase C (Welburn \& Murphy 1998), a serine threonine protein kinase and a leucine zipper protein. Genes related to cell cycle control include prohibitin (Welburn \& Murphy 1998). Mitochondial involvement in ConA induced cell death is implied by the identification of a cDNA with homology to a mitochondrial RNA splicing protein, a mitochondrial transporter and cytochrome $\mathrm{c} 1$. A homologue to the histone $\mathrm{H} 3$ has also been identified.

\section{DISCUSSION}

The accumulating evidence for PCD/apoptosis in single celled organisms is suggestive of of an ancestral death machinery (Fraser \& James 1998). The prediction that a single core molecular mechanism of PCD emerging in evolution prior to the postulated multiple emergences of multicellularity would dictate that some of the molecules involved in the core PCD mechanism of even phylogenetically very distant organisms should be related (Cornillion et al. 1994).

The genes described here represent the first endogenous genes to be identified as implicated in cell death in unicellular organisms. While it is evident that some of the genes involved in cellular suicide in trypanosomes are conserved in higher organisms, with the exception of cyctochrome $\mathrm{c} 1$ (upstream of cytochrome $\mathrm{c}$ in the electron transport chain) none of the genes described here have previously been directly implicated in either apoptosis or PCD in mammals. Cytochrome $\mathrm{c}$ is a prime initiator of apoptosis in mammalian cells acting downstream of bcl-2 and being released from mitochondria during apoptosis (Garland \& Rudin 1998).

Two further genes which are up-regulated late during Con A induced cell death in $T$. $b$. rhodesiense which have homologues in multicellular organisms and which may have an indirect role in apoptosis in metazoan systems are prohibitin and TRACK (Welburn \& Murphy 1998).

Prohibitins are a family of highly conserved nuclear encoded mitochondrial proteins which interact with a homologous protein BAP37, these proteins are implicated in cell cycle regulation, senescence and tumour suppression in mammals and in determining yeast replicative lifespan - the double knockouts showing an $80 \%$ reduction in mitochondrial membrane potential (Coates et al. 1997). Expression of prohibitin RNA in $T$. $b$. rhodesiense is relatively low in normal actively dividing cells and only enhanced after stimulation with Con A, with maximum expression at $24 \mathrm{hr}$. Trypanosomes also possess a BAP37 homologue, recently identified by the trypanosome genome sequencing project. Prohibitins have not previously been associated with cell death in multicellular organisms although mutants in the $\mathrm{Cc}$ gene in Drosophilla fail to develop past the embryonic stage (Eveleth \& Marsh 1986).

A role for prohibitins in mitochondrial inheritance and in the regulation of mitochondrial morphology has recently been suggested since, in $S$. cerevisiae, phb1 or phb2 mutations were lethal when combined with a mutant for any of three mitochondrial inheritance components of the mitochondrial outer membrane, Mdm12p, Mdm10p, 
and Mmm1p. In addition loss of function of either prohibitin in cells with mitochondrial DNA deleted led to altered mitochondrial morphology (Berger \&Yaffe 1998). Although prohibitins have not been implicated in either apoptosis in mammalian cells or PCD in the nematode worm, evidence is accumulating that the nuclear features of apoptosis are preceded by alterations in mitochondrial function and structure (Petit et al. 1997).

TRACK is a member of the RACK gene family which are homologues of the beta sub-unit of $\mathrm{G}$ proteins and which are intracellular receptors for activated protein kinase C. TRACK RNA increased during cellular death of procyclic T. $b$. rhodesiense with maximal expression $48 \mathrm{hr}$ after Con A treatment (Welburn \& Murphy 1998), suggestive of a role for protein kinase $\mathrm{C}$ in cell death in trypanosomes. In other systems RACK1 has been shown to be an Src tyrosine kinase binding protein which can inhibit the kinase activity of Src and Lck tyrosine kinases. Cells over-expressing RACK1 exhibit decreased tyrosine phosphorylation on many cellular proteins with cellular growth being depressed by up to 50\%. RACK1 over-expressing cells do not show an increased rate of necrosis or apoptosis but exhibit a prolongation in G0/G1 (Chang et al. 1998). Despite the high level of conservation between the genes implicated in cell death in trypanosomes and their mammalian homologues, neither gene described here has been previously directly implicated in PCD in mammals although an indirect role for protein kinase $\mathrm{C}$ has been proposed.

In this study a high percentage of differentially expressed cDNAs correspond to ribosomal proteins and it is unclear whether ribosomal protein genes play an active role in the death programme or whether this reflects metabolic disturbance of the dying cell. A similar percentage of ribosomal proteins were identified in a differential screen of rat glioma cells after induction of apoptosis and this was considered indicative of a possible involvement of the cellular translational apparatus in the death process (Baudet et al. 1998).

Several studies in yeast do suggest that an evolutionarily conserved metazoan PCD pathway may operate in single-celled organisms (Fraser \& James 1998). Genes which affect developmental PCD in C. elegans, and apoptosis in mammals have been shown to function in yeast which lack such endogenous genes. Bax (which drives a mammalian cell towards death) and Bcl-2 (which suppress programmed cell death) have both been shown to be functionally active in yeast cells, either driving the cell towards death or protecting the yeast cell from death (Ink et al. 1997, Jurgensmeier et al. 1997). The principal genes involved in PCD in C. elegans also appear to function in a similar manner in
Schizosachromyces pombe. Induction of wild-type ced-4 expression in S. pombe resulted in rapid focal chromatin condensation and lethality. Co-expression of ced-9 (which prevents the death-promoting actions of ced-4 in C. elegans) similarly prevented ced-4-induced death in yeast (James et al. 1997).

In conclusion, it is evident that several genes which affect apoptosis in mammalian systems and PCD in C. elegans function in a similar manner in single celled yeast which does not possess endogenous homologues for such genes. Whether members of the Trypanosomatidae and other singlecelled organisms would be able to respond to these principal effectors and supressors of mammalian and invertebrate $\mathrm{PCD} /$ apoptosis remains unclear at present. The identification of novel genes that regulate cell suicide in these unicellular organisms (the most primitive eukaryote in which PCD has been described) is essential to establish whether unicellular eukaryotes do share the same or similar regulators of cell suicide programmes with multicellular organisms. An understanding of cell death processes in these parasites may also offer new possibilities for controlling parasitic disease (Ameisen 1996, Welburn et al. 1997). The extent of the overlap between effectors and regulators of PCD between trypanosomatid and mammalian host PCD pathways may determine whether or not the pathways leading to cell suicide in these parasites may be exploited as a parasite control strategy (Welburn et al. 1997).

\section{ACKNOWLEDGEMENTS}

To Dr Davis Ellis and George Tovey from the London School of Hygiene and Tropical Medicine, London for the electron micrographs.

\section{REFERENCES}

Altschul SF, Gish W, Miller W, Myers EW, Lipman DJ 1990. Basic local alignment search tool. J Mol Biol 215: 403-410.

Altschul SF, Madden TL, Schaffer AA, Zhang J, Zhang Z, Miller W, Lipman DJ 1997. Gapped BLAST and PSI-BLAST: a new generation of protein database search programs. Nucleic Acids Res 25: 3389-3402.

Ameisen JC, Idziorek T, Billaut-Mulot O, Loyens M, Tissier JP, Potentier A, Ouaissi A 1995. Apoptosis in a unicellular eukaryote (Trypanosoma cruzi): implications for the evolutionary origin and role of programmed cell death in the control of cell proliferation, differentiation and survival. Cell Death Differ 2: $285-300$

Amiesen JC 1996. The origin of programmed cell death. Science 272: 1278-1279.

Arends MJ, Wyllie AH 1991. Apoptosis: mechanisms and roles in pathology. Int Rev Exp Pathol 32 :223-254.

Azizeh BY, Cribbs DH, Kreng VM, Cotman CW 1998. Cross-linking of NCAM receptors on neurons induces programmed cell death. Brain Res $796: 20-26$ Baudet C, Perret, E, Delpech B, Kaghad M, Brachet P, 
Wion D, Caput D 1998. Differentially expressed genes in C6.9 glioma cells during vitamin D-induced death program. Cell Death Differ 5:116-125.

Berger, KH, Yaffe, MP 1998 Prohibitin family members interact genetically with mitochondrial inheritance components in Saccharomyces cerevisiae. Mol Cell Biol 18: 4043-4052.

Chang BY, Conroy KB, Machleder EM, Cartwright CA 1998. RACK1, a receptor for activated $C$ kinase and a homolog of the beta subunit of $\mathrm{G}$ proteins, inhibits activity of src tyrosine kinases and growth of NIH 3 T3 cells. Mol Cell Biol 18: 3245-3256.

Coates PJ, Jamieson DJ, Smart K, Prescott AR, Hall PA 1997. The prohibitin family of mitochondrial proteins regulate replicative lifespan. Current Biol 7: 607-610.

Cornillon S, Foa C, Davoust J, Buonavista N, Gross JD, Golstein P 1994. Programmed cell death in Dictyostelium. J Cell Sci 107: 2691-2704.

Cribbs DH, Kreng VM, Anderson AJ, Cotman CW 1996. Cross-linking of concanavalin A receptors on cortical neurons induces programmed cell death. Neuroscience 75 : 173-185.

Cunningham I 1977. New Culture medium for maintenance of tsetse tissues and growth of trypanosomatids. J Protozool 24: 325-329.

Eveleth DD, Marsh JL 1986. Sequence and expression of the $\mathrm{Cc}$ gene, a member of the dopa decarboxylase gene cluster of Drosophila: possible transcriptional regulation. Nucleic Acids Res 14: 6169-6183.

Evan GI, Wyllie AH, Gilbert CS, Littlewood TD, Land H, Brooks M, Waters CM, Penn, LZ, Hancock DC 1992. Induction of apoptosis in fibroblasts by c-myc protein. Cell 69: 119-128.

Fraser A, James C 1998. Fermenting debate: do yeast undergo apoptosis? Trends Cell Biol 8: 219-221.

Fotedar R, Fotedar A 1995. Cell cycle control of DNA replication. Prog Cell Cycle Res 1: 73-89.

Garland JM, Rudin C 1998. Cytochrome c induces caspase-dependent apoptosis in intact hematopoietic cells and overrides apoptosis suppression mediated by bcl-2, growth factor signaling, MAP-kinase-kinase, and malignant change. Blood 15: 1235-1246.

Hengartner MO 1997. Genetic control of programmed cell death and ageing in the nematode Caenorhabditis elegans. Exp Gerontol 32: 363-74.

Ink B, Zornig M, Baum B, Hajibagheri N, James C, Chittenden T, Evan G 1997. Human Bak induces cell death in Schizosaccharomyces pombe with morphological changes similar to those with apoptosis in mammalian cells. Mol Cell Biol 17: 2468- 2474.

James C, Gschmeissner S, Fraser A, Evan GI 1997. CED-4 induces chromatin condensation in Schizosaccharomyces pombe and is inhibited by direct physical association with CED-9. Curr Biol 7: 246-252.

Janssen, O., Scheffler, A. and Kabelitz, D 1993. In vitro effects of misletoe extracts and mistletoe lectins Cytotoxicity towards tumor cells due to the induction of programmed cell death (apoptosis). Drug Res 43: 1221-1227.

Jurgensmeier JM, Krajewski S, Armstrong RC, Wilson GM, Oltersdorf T, Fritz LC, Reed JC, Ottilie S 1997. Baxand Bak-induced cell death in the fission yeast
Schizosaccharomyces pombe. Mol Biol Cell 8: 325-339.

Kim M, Rao MV, Tweardy DJ, Prakash M, Galili U, Gorelik E 1993. Lectin-induced apoptosis of tumour cells. Glycobiology 3: 447-453.

King KL, Cidlowski JA 1995. Cell cycle and apoptosis: common pathways to life and death. J Cell Biochem 58: $175-180$.

Kong SK, Suen YK, Chan CW, Choy YM, Fung KP and Lee CY 1996. Concanavalin A-induced apoptosis in murine macrophages through a $\mathrm{Ca}^{2+}$ - independent pathway. Cell Death Differ 3: 307-314.

Larsen CJ 1994 The BCL2 gene, prototype of a gene family that controls programmed cell death. Ann Genet 37: 121-34.

Lowe SW, Schmitt EM, Smith SW, Osborne BA, Jacks T 1993. p53 is required for radiation-induced apoptosis in mouse thymocytes. Nature $362: 847-849$.

Moreira ME, Del Portillo HA, Milder RV, Balanco JM, Barcinski MA 1996 Heat shock induction of apoptosis in promastigotes of the unicellular organism Leishmania (Leishmania) amazonensis. J Cell Physiol 167: 305-313.

Murphy NB, Pelle R 1994 The use of arbitrary primers and the RADES method for the rapid identification of developmentally regulated genes in trypanosomes. Gene 141: 53-61.

Murphy NB, Welburn SC 1997. Programmed cell death in procyclic Trypanosoma brucei rhodesiense is associated with differential expression of mRNAs. Cell Death Differ 4: 365-370.

Picot, S Burnod J, Bracchi V, Chumpitazi BF, AmbroiseThomas P 1997. Apoptosis related to chloroquine sensitivity of the human malaria parasite Plasmodium falciparum. Trans $R$ Soc Trop Med Hyg 91: 590-591.

Petit PX, Zamzami N, Vayssiere JL, Mignotte B, Kroemer $\mathrm{G}$, Castedo M 1997. Implication of mitochondria in apoptosis. Mol Cell Biochem 174: 185-188.

Richardson JP, Beecroft DL, Tolson DL, Liu MK, Pearson, TW 1988. Procyclin: an unusual immunodominant glycoprotein surface antigen from the procyclic stage of African trypanosomes. $\mathrm{Mol}$ Biochem Parasitol 31: 203-216.

Scheipers P, Reiser H 1998. Fas-independent death of activated CD4(+) T lymphocytes induced by CTLA4 crosslinking. Proc Natl Acad Sci USA 95: 1008310088.

Trauth BC, Klas C, Peters AM, Matzku S, Moller P, Falk W, Debatin KM, Krammer PH 1989. Monoclonal antibody-mediated tumor regression by induction of apoptosis. Science 245: 301-305.

Welburn SC, Dale C, Ellis D, Beecroft R, Pearson TW 1996. Apoptosis in procyclic Trypanosoma brucei rhodesiense in vitro. Cell Death Differ 3: 229-236.

Welburn SC, Williams GT, Barcinski MA 1997. Programmed Cell Death in Trypanosomatids. Parasitol Today 13: 22-25.

Welburn SC, Murphy NB 1998. Prohibitin and RACK homologues are up-regulated in trypanosomes induced to undergo apoptosis and in naturally occurring terminally differentiated forms. Cell Death Differ 5: 615-622.

Wyllie AH, Kerr JFR, Curry, AR 1980. Cell death: the significance of apoptosis. Int Rev Cytol 68: 251-306. 